disease which previously resisted all attempts at control. Considerable progress in the investigation on the control of the peach moth is reported by the Division of Economic Entomology and very favourable results have been obtained with nicotinekentonite-sulphur sprays. The same Division has been responsible for work on termite control, while the work carried out on the control of weeds has been considerably extended by reorganizing the botanical and entomological phases in one section under joint control of the chiefs of the two Divisions. The Division of Animal Health Nutrition has been responsible for investigations on pleuro-pneumonia in cattle and on the treatment of internal parasites of sheep, while its fundamental investigations on the nutrition of sheep have already led to an increase of nearly 150 per cent in the yield of wool as well as to a remarkable variation in its character. Valuable contributions to viticulture and regarding the role of organic matter in plant nutrition have been made by the Soils Division, while the Food Preservation Section has obtained promising results in investiga. tions on the storage of peaches and plums from the point of view of export to Great Britain which should decrease the wastage in export. The Radio Research Board has continued its investigations; appreciable advance in the control and eradication of prickly pear by biological methods is again reported, and a programme of fisheries research has also recently been initiated.

\section{National and International Standardization}

REALIZATION of the advantages of standardization of industrial materials and requirements has led in most of the industrially developed countries to the establishment of organizations to promote such standardization, and already a high degree of standardization has been reached in many countries. A most informative account of the work of the various national authoritative bodies engaged in this work is given in "A Survey of the Present Organization of Standardization-National and International", published by the World Power Conference. In Great Britain, the British Standards Institution is the national standardizing organization and is responsible for the determination of British standard specifications. Though the Institution has a strict rule that it does not initiate standardization but waits to be approached by a recognized outside authority such as a trade association, technical institution, or Government department, it has already issued more than 560 British Standard Specifications, exclusive of some 160 specifications for aireraft materials and components issued in co-operation with the Air Ministry.

INTERNATIONAL standardizing organizations, such as the International Federation of the National Standardizing Associations (ISA) or the International Electrotechnical Commission (IEC) have also been established. ISA, for example, federates the national standardizing organizations of nineteen countries and was founded in New York in 1926 with the object of promoting co-operation, co-ordination and interchange of information. But international co-operation, in contrast to the development of standardization along national lines, has made slow progress. It was indeed the need for further development in this direction that led the International Executive Council of the World Power Conference to initiate this inquiry, and the report has been published with the hope that it may serve as a stimulus to a greater degree of co-operation in national standardization and to a closer co-ordination of the activities of international organizations engaged in standardization, to the end that duplication and overlapping may be avoided and international standardization may be more speedily effected.

\section{Scientific Basis of Birth Control}

IN Science and Society of June-September 1937 , there appears an article on "The Scientific Basis of Birth Control" by Dr. C. V. Drysdale, president of the Malthusian League. The author remarks that the true, present-day application of the Malthusian doctrine may best be understood by reference to the affairs of an ordinary married couple. "The average young man marries when his income is sufficient to support a wife and perhaps one child, and, if that income were fixed, every additional child would mean a lowering of the family standard of existence." But, in many occupations, salaries rise with age and service, and if additional children come when there has been a sufficient rise in income, no lowering of the standard need take place. "This is the population problem as it confronts almost every middle-class couple." If children arrive at a greater rate than can be allowed for by increases of salary, then such a family is "over-populated". It amounts to this, that, in general, in civilized countries, birth-control has assisted in the preservation of the amenities and standards of living. Another aspect of birth-control is, of course, its application to what is called negative eugenics, that is, the avoidance of parenthood by persons afflicted with transmissible disease or defect. Dr. Drysdale looks forward to a future in which a planned social economy shall ensure general early marriage with reasonable family limitation. But it will be necessary to arrange that the limitation does not go too far, and the question is: How ?

\section{Fauna of the U.S.S.R.}

Some years before the Great War, the Russian Academy of Sciences launched an ambitious scheme of publishing detailed monographs on all groups of animals occurring within the Russian Empire and in neighbouring countries, under the title "Faune de la Russie et de pays limitrophes". The programme of the publication was so extensive that the first few volumes which appeared were sufficient to show the virtual impossibility of continuing the work on the same scale. The idea, however, was not abandoned, and the Academy of Sciences of the U.S.S.R. has now commenced the publication of a new "Faune de l'URSS", which aims at giving a full, but concisely written, monographic treatment mainly 